\title{
MODEL COLLABORATIVE LEARNING BERBANTUAN MEDIA EKSPRESOMATIKA TERHADAP LITERASI MATEMATIKA SISWA SEKOLAH DASAR
}

\author{
${ }^{1}$ Nuhyal Ulia, ${ }^{2}$ Rany Dwi Saputri, ${ }^{3}$ Rida Fironika Kusumadewi \\ nuhyalulia@unissula.ac.id \\ Prodi PGSD Universitas Islam Sultan Agung
}

\begin{abstract}
ABSTRAK
Penelitian ini bertujuan untuk mengetahui keefektifan model collaborative learning berbantuan media ekspresomatika terhadap kemampuan literasi siswa sekolah dasar. Penelitian dilakukan di kelas eksperimen yang menggunakan model collaborative learning dan kelas kontrol dengan model konvensional dengan desain penelitian adalah True Eksperimen Desain, berbentuk Posttest Only Control. Teknik pengambilan data ke dua kelas dilakukan dengan instrumen yang sama. Dari data yang diperoleh akan dilakukan pengujian normalitas, homogenitas, dan uji banding dua rata-rata untuk mengetahui keadaan masing-masing kelas sebelum diberi perlakuan dan sesudah diberi perlakuan. Kemudin akan dilakukan pengujian hipotesis dari data akhir untuk mengetahui model mana yang lebih efektif digunakan dalam pembelajaran. Pengujian hipotesis dilakukan dengan uji t, dari hasil perhitungan hipotesis yang telah dilakukan peneliti terkait kemampuan literasi matematika diperoleh nilai thitung sebesar $-0,315$ dan tabel sebesar 1,992 dengan taraf signifikan 0,05 . Karena $-t_{\text {tabel }}(-1,992) \geq t_{\text {hitung }}(-0,315) \leq t_{\text {tabel }}$ $(1,992)$ sehingga Ho ditolak dan Ha diterima. Dengan begitu dapat disimpulkan bahwa kemampuan literasi matematika siswa dengan menggunakan model collaborative learning berbantuan media ekspresomatika lebih baik atau sama terhadap kemampuan literasi matematika siswa dengan menggunakan model konvensional.
\end{abstract}

Kata Kunci: Model Collaborative Learning, Media Ekspresomatika, Literasi Matematika,

\section{PENDAHULUAN}

Perkembangan era globalisasi seperti yang terjadi saat ini mengarahkan setiap masyarakat untuk berkompetisi dalam berbagai bidang agar tidak tertinggal oleh negara lainnya. Pada masa perkembangan seperti saat ini tidak hanya mereka yang mengerti tentang ilmu, menghafal banyak ilmu dan memahami ilmu saja yang dibutuhkan. Lebih dari itu, masyarakat saat ini dituntun untuk dapat menghubungkan, mengelola, mengaplikasikan dan menerapkan ilmu tersebut sehingga dapat meningkatkan kecerdasan dan 
keterampilan dalam diri masing-masing individu.

Banyak sekali faktor yang dapat mempengaruhi tingkat kecerdasan dan keterampilan dalam diri seseorang, salah satu faktor yang sangat mempengaruhi dan menunjang kecerdasan maupun keterampilan seorang individu yaitu dalam lingkup dunia pendidikan. Pendidikan sendiri memiliki makna dan arti yang beragam, Nofiejantie (2014:46) menyatakan bahwa "pendidikan merupakan upaya yang terencana dalam proses pembimbingan dan pembelajaran bagi individu agar berkembang dan tumbuh menjadi manusia yang mendiri, bertanggung jawab, kreatif, berilmu, sehat, dan berakhlak mulia baik dilihat dari aspek jasmani maupun rohani”.

Dari pendapat tersebut dapat disimpulkan bahwa pendidikan upaya dalam diri seseorang untuk berkembang, tumbuh dan meningkatkan kemampuan yang ada didalam diri individu tersebut secara terencana dan tersusun.

Salah satu cara untuk memajukan suatu negara yaitu dengan mengembangkan sumber daya manusia dan utamanya melalui pendidikan nasional atau tingkatan pada jenjang pendidikan formal. Pendidikan formal merupakan "jalur pendidikan yang terstruktur dan berjenjang yang terdiri atas pendidikan dasar, pendidikan menengah pertama, pendidikan menengah atas dan perguruan tinggi” (Anwas, 2013:52). Selain itu pendidikan formal merupakan satu-satunya jalur pendidikan yang mengadakan dan menerapkan adanya proses belajar secara tersusun, sistematis dan rinci dengan mengikuti peraturan ataupun ketetapan dari lembaga pendidikan nasional di suatu negara. Penyelenggaraan pendidikan formal di negara Indonesia sendiri telah diatur berdasarkan dengan rancangan dan sistematika yang disebut Kurikulum. Kurikulum yang berlaku di Negara Indonesia adalah Kurikulum 2013 dan Kurikulum KTSP.

Proses pembelajaran dengan menerapkan kurikulum 2013 menekankan aspek afeketif, aspek kognitif, dan aspek psikomotorik. Untuk mengetahui permasalahan lainnya terutama pada tingkat kemampuan literasi matematika siswa, kegiatan observasi dilakukan dengan cara membagikan soal cerita pelajaran matematika siswa kelas I yang dikaitan dengan subtema sebelumnya dan meminta siswa untuk mengerjakan tanpa membahas ulang materi tersebut. Dari soal yang telah dikerjakan oleh siswa 
menunjukkan bahwa kemampuan literasi matematika siswa kelas 1 SD Negeri Karangroto 01 masih rendah.

Berdasarkan hasil observasi tersebut, peneliti akan mencoba menggunakan model collaborative learning berbantuan media ekspresomatika untuk meningkatkan kemampuan literasi matematika siswa terutama pada pembelajaran matematika. Penggunaan model collaborative learning berbantuan media ekspresomatika dalam penelitian digunakan sebagai stimulus baru dalam menyampaikan materi pembelajaran, dan sebagai upaya menciptakan proses belajar yang lebih maksimal. Sesuai dengan teori koneksionisme dalam pandangan Thorndike dengan menciptakan adanya stimulus baru dalam pembelajaran dapat menimbulkan respon yang baik dari siswa. Dengan adanya respon tersebut akan berpengaruh terhadap kualitas pada aspek kognitif, afektif, dan psikomotor. Perubahan kualitas siswa terutama pada aspek tersebut sesuai dengan pandangan Bloom terhadap teori belajar.

Tujuan pembelajaran matematika tidak sekedar membuat siswa memiliki kemampuan berhitung saja. Adapun usaha lainnya yaitu membuat siswa agar memiliki kemampuan logis dan kritis. Dengan kemampuan tersebut melatih siswa agar tidak hanya dapat memecahkan masalah yang bersikap runtut atau rutin, tetapi lebih kepada penyelesaian masalah terkait dengan kehidupan sehari-hari dan penerapannya. Kemampuan matematis yang demikian yang dikenal dengan kemampuan literasi matematika. Salah satu ahli menjelaskan tentang kemampuan literasi, Johar (2012:32) "kemampuan literasi matematika diartikan sebagai kemampuan seseorang untuk merumuskan, menggunakan dan menafsirkan matematika dalam berbagai konteks, termasuk kemampuan melakukan penalaran secara matematis dan menggunakan konsep, prosedur, dan fakta untuk menggambarkan kejelasan". Tidak hanya itu, kemampuan literasi matematika memiliki cangkupan domain konten dan domain kognitif. Kemampuan tersebut harus dilatih, diterapkan, dan dikuasi oleh siswa agar memudahkan mereka ketika menyelesaikan dan mencari rumusan masalah baik dalam soal matematika maupun kehidupan sehari-hari.

Berdasarkan latar belakang yang telah diuraikan tersebut, maka permasalahan penelitian ini dapat 
diuraikan sebagai berikut: (a) dalam menganalisis soal cerita rasa ingin tahu siswa sangatlah kurang karena diberikan dalam bentuk bacaan. (b) banyak siswa yang mengalami kesulitan dalam memahami bacaan dan membutuhkan bimbingan dari guru secara bertahap untuk mencari rumusan masalah dalam soal cerita. (c) kurangnya kemampuan siswa dalam memahami suatu soal bacaan, sehingga siswa kesulitan dalam merumuskan, menggunakan, dan mendifinisikan rumusan masalah matematika. (d) banyak siswa yang mampu membaca namun sulit untuk memahami suatu soal bacaan, menganalisis, dan menafsirkan rumusan masalah tersebut secara maksimal. (e) banyak siswa yang mengalami kesulitan dalam memahami suatu soal bacaan, sehingga siswa sulit untuk membedakan antara penjumlahan atau pengurangan dalam soal cerita yang diberikan. (f) pada pembelajaran dikelas, model collaborative learning atau pembelajaran secara berkelompok dan penggunaan media ekspresomatika belum diterapkan.

\section{KAJIAN TEORI}

\section{A. Model Collaborative Learning}

Dalam kegiatan pembelajaran guru harus memiliki keterampilan dalam memilih penggunaan model pembelajaran. "Model merupakan suatu gambaran tentang sesuatu sehingga dapat memperjelas berbagai unsur-unsur yang terkait didalamnya" (Rosdiani, 2013:4). Dari pendapat tersebut disimpulkan bahwa model merupakan gambaran dari suatu pembelajaran yang akan digunakan, sehingga materi yang terkandung didalamnya dapat tersampaikan.

$\begin{array}{lrr}\text { Model } & \text { pembelajaran } & \text { dapat } \\ \text { membantu guru dalam } & \text { upaya } \\ \text { mengembangkan } & \text { kemampuan, }\end{array}$
kreatifitas dan potensi dalam diri siswa baik secara individu maupun kelompok. Namun pembelajaran secara individu akan lebih baik jika dipadukan dengan pembelajaran berbasis kelompok.

Pendapat lain dijelaskan oleh Barkley, dkk. (2016: 139) "kelas kolaboratif membuat siswa turut bertanggung jawab dan terlibat dalam proses pembelajaran, serta mendorong siswa untuk bekerja secara kolaboratif bukan kompetensi, dengan teman-teman dikelas". Dari kedua pendapat tersebut dapat disimpulkan penggunaan model 
collaborative learning yang dalam penerapannya dilakukan secara berkelompok dapat menuntun siswa untuk berinteraksi aktif dalam mengeluarkan ide, pendapat, dan gagasan terkait materi yang disampaikan didalam kelompok, sehingga dalam kelompok tersebut setiap anggota mendapatkan beragam pengetahuan.

Pendapat Rocca, dkk. (2014:62) tentang pengalaman belajar kolaboratif dalam kelompok berkontribusi pada perolehan pengetahuan siswa yang dibutuhkan untuk menyelesaikan pembelajaran mereka sendiri dengan keuntungan dan kesuksesan. Sebagaima ditemukannya bahwa: "argues that the experiences of collaborative learning contribute meta-knowledge required to complete their own learning with profit and sucses". Dari pendapat tersebut dijelaskan bahawa penggunaan model Collaborative Learning dalam pembelajaran secara kolaborasi membantu siswa dalam menambah pengetahuanya dan pemahaman secara mendalam dari materi yang disampaikan, sehingga memudahkan siswa dalam menyelesaikan masalah belajar secara mandiri dan membentuk kelas yang efektif.
Tujuan pembelajaran dengan menggunakan model collaborative learning yang dilaksanakan secara berkelompok bukan sekedar mencapai kesatuan atau persamaan pengetahuan yang didapat dalam kegiatan kelompok tersebut, namun mendorong siswa untuk menemukan berbagai pengetahuan, ideide, dan informasi terkait materi yang dikeluarkan maupun dikuasai oleh masing-masing anggotanya. Dengan kemampuan yang didapat dalam kelompok belajar dapat diimplementasikan atau diaplikasikan oleh siswa ketika mencari rumusan masalah secara individu.

\section{B. Media Ekspresomatika}

Media pembelajaran memiliki makna yang luas, Uno (2014: 114) berpandapat bahwa "media adalah semua alat komunikasi yang digunakan untuk menyampaikan atau memberikan informasi dari sumber kepada peserta didik, dengan tujuan merangsang mereka untuk mengikuti kegiatan pembelajaran". Dari pendapat tersebut dapat disimpulkan bahwa media merupakan alat yang sengaja dirancang oleh guru sebagai sumber informasi terkait dengan materi pembelajaran, sehingga dapat membantu dan 
membentuk adanya umpan balik antara guru dan siswa.

Media ekspresomatika merupakan media yang menggunakan perkembangan teknologi komputer. Darmawan (2017: 54) menjelaskan "komputer tidak hanya dimainkan dan digunakan untuk meningkatkan ilmu atau pengetahuan yang harus dipelajari siswa (computer as science), tetapi komputer sebagai alat yang dapat membantu mempelajari berbagai materi pelajaran (computer as tools)". Dari pendapat tersebut dapat disimpulkan bahwa komputer memiliki fungsi lainnya yang dapat digunakan untuk menyampaikan materi pembelajar dan tidak hanya digunakan untuk belajar dan praktik ketika mata pelajaran Teknologi, Informasi, dan Komunikasi (TIK) di sekolah.

Selain berfungsi dalam menyampaikan materi, Anwariningsih dan Ernawati mengemukakan keunggulan dalam penggunaan media komputer, yaitu: "Provide a more affective condition so it can accommodate students who are slow in accepting the lesson, stimulate students in doing exercises, and the absolute students control of learning so that the level of learning speed of the students can be matched to the level of control". Dari keunggulan penggunaan media komputer tersebut dapat mendorong terbentuknya kelas yang kondusif dalam pembelajaran, sehingga dapat muncul rasa ingin tahu siswa terhadap materi pembelajaran. Media ekspresomatika merupakan media pembelajaran berbantuan LCD proyektor dan laptop dalam penerapannya.

\section{Kemampuan Literasi}

Banyak orang yang beranggapan kemampuan menulis dan membaca adalah kemampuan dari cabang mata pelajaran bahasa indonesia dan kemampuan berhitung adalah kemampuan dari cabang mata pelajaran matematika. Namun, mata pelajaran matematika juga memiliki kaitanya dengan kemampuan membaca dan menulis. Hal tersebut dapat dibuktikan dengan adanya soal matematika berbasis soal cerita yang sering dikaitkan dengan kehidupan sehari-hari dan memburuhkan kemampuan pemahaman terhadap isi teks soal tersebut, dimulai dengan mengaitkan kemampuan membaca.

Namun tidak semua siswa dapat memahami isi teks dalam soal cerita tersebut, sehingga siswa mengalami 
kesulitan dalam mencari rumusan masalah yang dihadapinya. Priyatni dan Nurhadi (2017:160) mengungkapkan "keterpahaman terhadap teks dapat membantu keterpahaman terhadap kehidupan dan berbagai aspeknya, karena itu representasi atau ide dari kehidupan individu agar bermakna bagi orang lain". Dari pendapat tersebut dapat disimpulkan bahwa kemampuan membaca mempengaruhi kemampuan siswa dalam mencari rumusan masalah khususnya pada mata pelajaran matematika, secara runtut dan sering dikaitkan dengan kehidupan sehari-hari, Kemampuan matematis yang demikian disebut dengan kemampuan literasi matematika atau yang biasa disebut dengan melek matematika.

Dengan kemampuan literasi matematika yang dimiliki siswa akan membantu mereka untuk memahami, menyadari, dan menerapkan konsep matematika mana yang relevan digunakan dalam upaya mencari rumusan masalah yang dihadapi dalam kehidupan. Johar (2012:32) menjelaskan bahwa "literasi atau melek matematika merupakan tingkat kemampuan individu dalam merumuskan, menggunakan, dan mendifinisikan matematika ke berbagai konteks segi kehidupan". Selain itu pendapat tersebut diperkuat oleh Firdaus, dkk. (2017:214) yang memandang definisi kemampuan membaca matematika adalah: "Mathematical literacy defined as the abillity of a person (in this case, students) to formulate, implement, and interpret Mathematics in varios contexts, including the ability to perfrom reasoning Mathematically and using the concepts, procedures, and facts to describe, explain, or predict phenomena / events".

Dari pendapat diatas dapat disimpulkan bahwa kemampuan literasi matematika dapat mempermudah seorang individu ketika menghadapi masalah matematika terkait kehidupan sehari-hari dengan mengaitkan kemampuan tersebut dan merumuskan, menggunakan, dan mendefinisikan masalah terkait konteks matematika. Selain itu, kemampuan literasi matematika mememiliki cangkupan yaitu domain konten dan domain kognitif. Untuk domain konten meliputi tiga domain, yaitu: bilangan, geometri, dan paparan data. Sedangkan domain kognitif merupakan perilaku yang diharapkan ada dalam diri ketika mereka berhadapan atau mencari rumusan masalah dari domain matematika. 
Domain kognitif terdiri atas tiga domain yaitu: (a) pengetahuan (Knowing), (b) penerapan (Applying), (c) Penalaran (Reasoning).

\section{METODE PENELITIAN}

Desain yang digunakan dalam penelitian ini adalah True Experimental Design. Populasi dalam penelian ini yaitu seluruh siswa kelas dasar, kemudian sampelnya seluruh siswa kelas 1 SD Negeri Karangroto 01 Semarang. Sampel dibagi menjadi dua yaitu kelas eksperimen dan kelas kontrol. Untuk kelas eksperimen siswa berjumlah 39 dan siswa kelas kontrol berjumlah 39 siswa.

Teknik pengumpulan data dilakukan untuk mengumpulkan semua data terkait dengan variabel penelitian. Instrumen dalam penelitian sebagai alat pengumpul data yang harus benar-benar dirancang untuk menunjang keberhasilan dari tujuan penelitian. Adapun instrument yang digunakan pada penelitian ini terdiri dari instrument tes, angket, wawancara dan dokumentasi. Intrumen tes digunakan untuk memperolah data tentang kemampuan literasi mateatika siswa SD. Pada teknik tes menggunakan teknik tes terlulis. dibutuhkan lembar kisi-kisi soal, kunci jawaban dan penskoran.

Soal yang diberikan berupa soal cerita yang dikaitkan dengan tema saat pembelajaran. Sebelum instrument tes digunakan perlu dilakukan uji coba instrument. Dalam hal ini meliputi uji validitas, reliabilitas, tingkat kesukaran dan daya pembeda. Uji coba intrumen diberikan selain daripada sampel penelitian. Dalam hal ini diberikan pada kakak kelas yang sudah pernah memperoleh materi tersebut.

Teknik pengambilan data selanjutnya adalah angket, sehingga diperlukan intstrumen lembar angket. Adapun lembar angket digunakan untuk pengambilan data afektif siswa. Selain itu, penelitian juga menggunakan instrument wawancara yang bertujuan sebagai bahan audensi ke siswa terutama terkait tentang kemampuan literasi matematika siswa. Wawancara ditujukan kepada guru kelas dan siswa.

Pada teknik dokumentasi, digunakan untuk analisis data awal. Data awal berupa dokumen nilai harian siswa pada materi sebelumnya. Untuk selanjutnya akan dianalisis dengan uji normalitas, uji homogentas dab uji kesamaan mdua rata-rata.

Adapun sebagai pelengkapnya 
Analisis data yang digunakan untuk menguji hipotesis adalah uji normalitas, uji homogenitas dan uji $\mathrm{t}$ banding. Hasil perhitungan analisis akan disesuaikan dengan criteria yang sudah dibuat.

\section{HASIL DAN PEMBAHASAN}

Berdasarkan perhitungan data awal dan data akhir, untuk mengetahui sikap rasa ingin tahu dan kemampuan literasi siswa Sekolah Dasar, dilakukan uji hipotesis. Adapun hasil perhitungannya yaitu pada hasil analisis data menggunakan uji t uji kesamaan dua rata-rata pada tabel 4.17 nilai $S_{\text {gabungan }}=11,969, t_{\text {hitung }}-0,315$ dan $t_{\text {tabel }}$ 1,992 dengan taraf signifikan distribusi 0,05 adalah 1,992. Pada perhitungan hipotesisi $2 \mathrm{H}_{0}$ ditolak dan $\mathrm{H}_{\mathrm{a}}$ diterima, karena - ttabel $\geq$ thitung $\leq$ ttabel yaitu $-1,992 \geq$ $0,315 \leq 1,992$. Sehingga dapat disimpulkan bahwa kemampuan literasi matematika siswa dengan menggunakan model collaborative learning dengan media ekspresomatika lebih baik atau sama terhadap kemampuan literasi matematika siswa dengan penerapkan model konvensional.

$$
\text { Pengolahan data akhir }
$$

berdasarkan instrument lembar tes kemampuan literasi matematika setelah pembelajaran dikenakan dengan model collaborative learning dan model konvensional. Adapun nilai kemampuan literasi data akhir telah dijelaskan pada lampiran 36 dan 37. Namun untuk hasil persentase masing-masing indikator kemampuan literasi matematika kelas pada setiap soal instrumen adalah sebagai berikut:

$$
\text { Berdasarkan hasil nilai }
$$
persentase indikator kemampuan literasi matematika pada masing-masing kelas akan dijelaskan dalam bentuk diagram sebagai berikut.

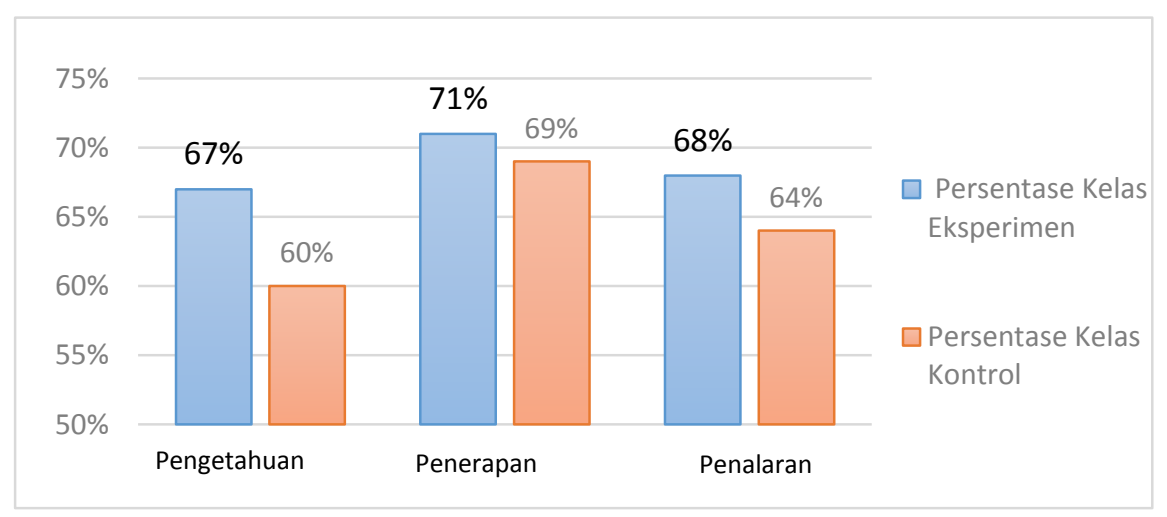

Grafik1. Grafik Kemampuan Literasi 
Dari grafik 1 diatas, ditunjukkan bahwa kemampuan siswa kelas eksperimen pada indikator pengetahuan sebesar $67 \%$ dan kelas kontrol sebesar $58 \%$. Pada indikator kedua yaitu penerapan nilai persentase kelas eksperimen sebesar 71\%, sedangkan kelas kontrol 68\%. Untuk indikator ketiga adalah penalaran persentase kelas eksperimen mencapai $68 \%$ dan kelas kontrol 64\%.

Kemampuan literasi data awal kelas eksperimen mencapai 66,282 dan 64,487. Sedangkan pada data akhir nilai rata kelas eksperimen mencapai 69,231 artinya lebih baik dari nilai rata-rata dari data awal sebelum pembelajaran diberikan dengan model collaborative learning, dan nilai rata-rata data akhir kelas kontrol menurun menjadi 63,333. Perbedaan nilai rata-rata data akhir dan data awal kelas eksperimen yang lebih baik membuktikan bahwa, pengunan mudel collaborative learning lebih efektif kemampuan literasi matematikas. Hal tersebut sesuai dengan pendapat Purwaktari (2015:110) yang mengemukakan "terdapat pengaruh positif dan signifikan penggunaan model collaborative learning terhadap kemampuan pemecahan masalah matematika siswa".Selain itu pendapat
Dermawan (2014:63) menjelaskan "kelas yang diberi perlakuan model pembelajaran collaborative learning menunjukkan hasil belajar yang lebih baik dibanding dengan kelas yang tidak menggunakan model tersebut". Selain itu penelitian yang dilakukan Inah dan Utami (2017:19) menjelaskan bahwa penggunaan model collaborative learning dalam pembelajaran mempengaruhi hasil belajar siswa diawal sebesar 57,72 menjadi 71,0. Tidak hanya itu pada pertemuan selanjutnya siswa telah memenuhi indikator kinerja yang telah ditetapkan oleh peneliti. Namun dalam penelitian tersebut model pembelajaran collaborative learning digunakan pada pembelajaran IPA, sedangkan pada penelitian ini diterapkan pada mata pelajaran matematika.

Dari pendapat tersebut dapat disimpulkan bahwa penggunaan model collaborative learning dalam pembelajaran memberikan pengaruh positif terhadap kemampuan siswa dalam memecahkan masalah matematika dan hasil belajar. Dalam penelitian ini kemampuan tersebut dilihat melalui kemampuan literasi matematika siswa, Namun hasil penggunaan model collaborative learning terhadap 
kemampuan literasi siswa tidak ada perbedaan dengan hasil peneliti tersebut. Artinya penggunaan model collaborative learning terhadap kemampuan literasi matematika siswa lebih efektif dari penggunaan model konvensional. Hal tersebut terlihat dari nilai rata-rata kelas eksperimen yang menggunakan model collaborative learning lebih baik dari nilai rata-rata siswa yang menggunkan model pembelajaran konvensional.

\section{SIMPULAN}

Berdasarkan hasil pengujian data, analisis, dan pembahasan terkait keefektifan model collaborative learning berbantuan media ekspresomatika terhadap kemampuan literasi siswa kelas I SD Negeri Karangroto 01 Semarang dikatakan lebih efektif. Kemampuan literasi siswa kelas eksperimen dengan menggunakan model collaborative learning lebih baik dari kemampuan literasi siswa kelas kontrol dengan dengan model konvensional. Hal tersebut ditunjukkan - ttabel $\geq$ thitung $\leq$ ttabel yaitu $-1,992 \geq-0,315 \leq 1,992$, maka dapat disimpulkan bahwa $\mathrm{H}_{0}$ ditolak dan $\mathrm{H}_{\mathrm{a}}$ diterima.

\section{DAFTAR PUSTAKA}

Anwas, M. (2012). "Pengaruh Pendidikan Formal, Pelatihan, dan Intensitas Pertemuanterhadap Kompetensi Penyuluhan Pertanian". Jurnal Pendidikan dan Kebudayaan. 19,(1), 50-62.

Anwariningsi, S.H dan Ernawati, S. (2013). "Development of Interactive Media for ICTLearning at Elementary School Based on Student Self Learning”. Jurnal of Education and Learning. 7, (2), 121-128.

Arifin, Z. (2014). Penelitian Pendidikan. Bandung: PT. Remaja Rosadakarya.

Arikunto, S. (2010). Prosedur Penelitian Suatu Pendekatan Praktik. Jakarta: Rineka Cipta.

Basrowi dan Suwandi. (2008). Memahami Penelitian Kualitatif. Jakarta: RinekaCipta.

Barkley, E.E., Cross, K.P dan Major, C.H. (2016). Collaborative LearningTechniques.Bandung: Nusa Media.

Dalyono, M. 2012. Psikologi Pendidikan. Jakarta: Rineka Cipta.

Darmawan, D. (2014). Inovasi Pendidikan. Bandung: Remaja Rosdakarya.

Departemen Pendidikan dan Kebudayaan. (2015). TIMSS Infographic. Jakarta:Depdikbud.

Dermawan, A. (2014). "Keefektifan Collaborative Learninfg Berbasis Quiz Edutaiment Terhadap Ketuntasan Hasil Belajar". Journal.Unnes. 3, (2), 57-63.

Dirman dan Jiarisih, C. (2014). Teori Belajar dan Prinsip-prinsip Pembelajaran yangMendidik. Jakarta: PT. Aneka Cipta. 
Djaelani, A.R. (2013). "Teknik Pengumpulan Data dalam Penelitian Kwalitatif". Majalah Ilmiah. 20, (1), 82-92.

Egiduis, G. (2017). Analisis Kemampuan Literasi Matematis Siswa Kelas VIII A SMP Pengudi Luhur Mayudan Tahun Ajaran 2016/2017. Skripsi pada FKIP Universitas Sanata Dharma Yogyakarta.

Firdaus, F.M, Wahyudi dan Herman, T. (2017). "Improving Primary Students Matematical Literacy Through problem based Learning and Direct Intruction". Journals Academic. 12, (14), 212-129.

Gurria. A. (2015). PISA 2015 PISA Results in Focus. [Online]. Tersedia: http://www.oecd.org/pisa/pisa2015-result -in-infocus.pdf[diunduh 22 Februari 2018].

Hanafy, M.S. (2014). "Konsep Belajar dan Pembelajaran". Jurnal Literasi Pendidikan. 17,(1), 66-79. 10, (1), 19-36

Inah, E.N dan Pertiwi, U.A. (2017). "Penerapan Collaborative Learnging Melalui Permainan Mencari Gambar Untuk Meningkatkan Hasil Belajar IPA Kelas $V$ di SDN Tabanggele Kecamatan Anggalomoare Kabupaten Konowe”. Jurnal AlTa'dib.

Johar, R. (2012). "Domain Soal PISA untuk Literasi Matematika". Jurnal Peluang. 1, (1), 30-41.

Lasidos, P, A dan Matondang, Z. (2015). "Peningkatan Model Pembelajaran Kolaboratifuntuk Meningkatkan Aktifitas dan Hasil Belajar Rencana Anggaran Biaya Siswa KelasXII Kompetensi Keahlian Teknik
Gambar Bangunam SMK 2 Siatas

Barita-TapanuliUtara". Jurnal

Education Building. 1, (1), 13-22.

Mahdiyah. (2014). Statistik Pendidikan. Bandung: Remaja Rosdakarya.

Mahmud. (2011). Metode Penelitian Pendidikan. Bandung: Pustaka Setia.

Margono. (2009). Metodeloogi Penelitian. Jakarta: Rineka Cipta.

Maolani, R dan Cahyana, U. (2015). Metodologi Penelitian Pendidikan. Jakarta: Rajawali Pres.

Mustika, M.V. (2014). Penerapan Model Pembelajaran Kolaboratif Teknik KWLH (Know-Want-Learned-How) untuk meningkatkan Rasa Ingin Tahu dan Prestasi Belajar IPA Materi Daur Ulang Air di kelas V SD Negeri 2 Mesri. Skripsi pada FKIP UMP Purwokerto: tidak diterbitkan.

Nofiejanti, L. (2014). "Peran Lembaga Pendidikan Formal Sebagai Modal UtamaMembangun Karakter Bangsa". Jurnal At-Tajdid. 3, (1), 4571.

Nuraini. (2013). Pengaruh Model Pembelajaran Collaborative Learning terhadap Kemampuan Pemecahan Masalah Matematika Siswa MTs Anshor Al-Sunnah Air Tiris Kabupaten Kampar. Skripsi pada FAI UIN Sultan Syarif Kasim Riau: tidak diterbitkan.

Octaviona, W. (2017). Meningkatkan Rasa Ingin Tahu Siswa pada Pembelajaran IPA Melalui Medel Discoveri Learning di Kelas V SD Negeri 186/1 Sridadi. Artikel Ilmiah pada FKIP Universitas Jambi.

Pluck, Graham dan Jonhson, H. (2011). "Stimulating Curiosity to Enhance 
Learnig”. JurnalEducation Science and Psychology. 2, (19), 24-31.

Priyatni, E.T dan Nurhadi. 2017. Membaca dan Literasi Kritis. Tangrang: Tira Smart.

Purwaaktari, E. (2015). "Pengaruh Model Collaborative Learning Terhadap Kemampuan Pemecahan Masalah Matematika dan Sikap Sosial Siswa Kelas V SD Jarakan Sewon Bantul". Jurnal Penelitian Ilmu Pendidikan. $8,(1), 95-111$.

Puspiasari, M.T, Santoso, S dan Muchsini, B. (2015). "Upaya Meningkatkan Karakter Rasa Ingin Tahu dan Hasil Belajar Belajar Akuntansi Melalui Pembelajaran Kontekstualdengan Motode Snowball Throwing pada Siswa SMK Muhammadyah 3 Gembolong".Jurnal "Tata Arta" UMS, 1, (1), 31-39.

Rocca, C.L., Margittini, M dan Capobianco, R. (2013). Collaborative Learning in HigherEducation: Scientific Research. Dalam Journal of Social Sciences (Online), 2, 6166.http://dx.doi.org/10.4236/jss.201 4.22009 .

Rosdiani, Dini. (2013). Model Pembelajaran Langsung dalam Pendidikan Jasmani dan Kesehatan. Bandung: Alfabeta.

Sari, R.H.N. (2015). "Literasi Matematika: Apa, Mengapa, dan Bagaimana?". Seminar Nasional Matematika dan Pendidikan Matematika UNY: Yogyakarta.

Santoso. S. (2013). "Pengaruh Model Pembelajaran Kolaboratif dan Motivasi Belajar Terhadap
Peningkatan Hasil Belajar Fisika Siswa Kelas X SMA Negeri 1 Purwantoro Wonogiri, Jawa Tengah”. V, (1), 15-19.

Sugiyono. (2015). Metode Penelitian Pendidikan.Bandung: Alfabeta.

Sulfasyah dan Arifin, J. (2016). "Implikasi Pendidikan Nonformal pada Remaja”. JurnalEquilibrium Pendidikan Sosiologi. IV, (2), 1-8.

Suprihatiningrum, J. 2017. Strategi Pembelajaran. Jogjakarta: Ar-Ruzz Media.

Sundayana, R. (2016). Statistika Penelitian Pendidikan. Bandung: Alfabeta.

Tanzeh, A. (2009). Pengantar Metode Penelitian. Yogyakarta: Teras.

Ulia, N. (2017). "Efektivitas Collaborative Learning Berbantuan Media Short Card Berbasis ICT Terhadap Kemampuan Pemahaman Konsep dan Kemampuan Literasi Matematika Siswa Sekolah Dasar”. Proposal Penelitian FKIP Unissula Semarang.

Uno, H.B. (2014). Profesi Pendidikan. Jakarta: Bumi Aksara.

Utomo, B.T. (2011). "Penerapan Pembelajaran Kolaboratif dengan Assesmen Teman Sejawat pada Mata Pelajaran Matematika SMP”. JP3, 1, (1), 52-61.

Widjajanti, D.B (2010). "Perkuliahan Kolaboratif Berbasis Masalah untuk Mahasiswa CalonGuru Matematika: Sebuah Ilustrasi". Makalah pada Seminar Nasional MatematikaUNY: Yogyakarta. 